\title{
Pemodelan pada Proses Cyclostationarity Berdasarkan Data Pasut Cilacap Tahun 2007-2015
}

\author{
LARASATI S. CENDANI, N. M. R. R. CAHYA PERBANI, KANIA SAWITRI
}

\author{
Jurusan Teknik Geodesi \\ FTSP - Institut Teknologi Nasional, Bandung \\ Email: larasatisricendani@gmail.com
}

\begin{abstract}
ABSTRAK
Sesuai prosedur dalam penentuan MSL sejati, pengamatan pasut dilakukan secara terus-menerus selama 18,61 tahun dengan selang waktu satu jam tanpa jeda. Pengamatan pasut tersebut bukanlah suatu hal yang mudah dan hampir tidak dapat untuk dilakukan, MSL yang digunakan untuk kepentingan teknis umumnya ditentukan berdasarkan data pengamatan pasut periode pendek selama 15 atau 29 hari. Periode pendek tersebut memiliki keterbatasan dalam mengakomodasi seluruh faktor yang mempengaruhi MSL. Hipotesis pada penelitian ini MSL bulanan juga memiliki sifat cyclostationarity berdasarkan penelitian pasang tinggi di Benoa, Bali yang memiliki sifat yang sama. Penelitian ini bertujuan memodelkan terjadinya proses cyclostationarity untuk dijadikan sebagai model koreksi mean sea level bulanan dan untuk mengetahui variasi yang terjadi. Pemodelan dilakukan menggunakan fungsi gelombang dua konstanta pasut periode panjang $S_{a}$ dan $S_{s a}$ menggunakan analisis harmonik kuadrat terkecil melalui Deret Fourier. Dari penelitian yang telah dilakukan diketahui bahwa model gelombang yang dihasilkan sudah $80 \%$ mewakili perilaku MSL bulanan dan simpangan maksimum terhadap MSL bulanan rata-rata sebesar $245 \mathrm{~mm}$.
\end{abstract}

Kata kunci: MSL bulanan, cyclostationarity, fungsi gelombang

\begin{abstract}
In procedure to determine the true mean sea level (MSL), hourly tide measurement should be taken for 18,61 years continuously. That such measurement is not simple and barely possible to establish. In most technical cases, MSL is determined from shot period measurement 15 or 29 days. The limitation of that such short period data is in accommodating all factors with action MSL. In this study the monthly MSL is a cyclostationarity process like spring tides in Benoa, Bali is taken as the hypothesis. This study directed to model cyclostationarity process to build the model of monthly MSL and to find it's variation. The modeling is accomplished using wave function two long period constituents $\left(S_{a}\right.$ and $\left.S_{s a}\right)$. Least square harmonic analysis by means of Fourier series is applied. It is found that the wave model from this study represent about $80 \%$ of monthly MSL behavior and the average of maximum deviation is $245 \mathrm{~mm}$.
\end{abstract}

Keywords: monthly MSL, cyclostationarity, wave function 


\section{PENDAHULUAN}

Dalam Mochamad (2008) dinyatakan bahwa Mean sea level (MSL) merupakan permukaan yang didefinisikan sebagai rata-rata tinggi permukaan laut setiap saat. MSL bukan merupakan bidang ekuipotensial. Bidang tersebut hanya menyebabkan adanya arus yang mengalir dari satu bidang ekuipotensial ke bidang ekuipotensial yang lain. Informasi MSL dalam bidang geodesi digunakan untuk keperluan penentuan datum tinggi dan chart datum yang digunakan untuk keperluan penentuan datum kedalaman. Perbani (2013) menyatakan bahwa terdapat berbagai definisi untuk MSL, di antaranya adalah: MSL merupakan permukaan laut yang bebas dari semua variasi yang bergantung pada waktu, yang disebut permukaan laut stasioner; MSL merupakan titik nol bagi ordinat dari komponen harmonik pasut dan permukaan laut tanpa gangguan pasut; MSL merupakan bidang tempat pasut berosilasi dan rata-rata suatu periode pengamatan yang panjang, sebaiknya selama 18,61 tahun.

Sesuai prosedur dalam penentuan MSL sejati, pengamatan pasut dilakukan secara terusmenerus selama 18,61 tahun dengan selang waktu satu jam tanpa jeda. Pengamatan pasut tersebut bukanlah suatu hal yang mudah dan hampir tidak dapat untuk dilakukan, khususnya di Indonesia sendiri belum ditemukan data pengamatan pasut selama 18,61 tahun yang lengkap. Namun, menurut Huang (1997) terdapat beberapa negara yang menyelenggarakan pengamatan selama 18,61 tahun, salah satu di antaranya adalah Taiwan dengan 3 stasiun pengamatan yaitu Huludao, Qinhuangdao, dan Kanmen. Adapun untuk memenuhi kepentingan teknis terutama bidang geodesi dibutuhkan data MSL sejati yang digunakan sebagai chart datum atau referensi dalam aspek pengukuran. Oleh karena itu untuk memenuhi kepentingan data teknis digunakan data MSL, sementara yang diperoleh dari pengamatan pasut selama 15 atau 29 hari. Pengamatan pasut yang pendek sebenarnya belum dapat dinyatakan benar dan bebas dari faktor kesalahan terutama untuk dijadikan referensi dalam aspek pengukuran. Oleh karena itu diperlukan adanya suatu koreksi yang diberikan agar data pengamatan pasut pendek tersebut dapat mewakili data MSL sejati.

MSL yang digunakan untuk kepentingan teknis umumnya ditentukan berdasarkan data pengamatan pasut periode pendek selama 15 atau 29 hari. Periode pendek tersebut memiliki keterbatasan dalam mengakomodasi seluruh faktor yang mempengaruhi MSL, di antaranya pengaruh gelombang pasut periode panjang. Berdasarkan penelitian studi proses cyclostationarity untuk prediksi pasut dari data pasut Benoa tahun 2006 sampai 2008 diketahui bahwa pasang tinggi di Benoa, Bali memiliki sifat cyclostationarity. Dalam hasil penelitian Perbani (2010) diketahui periode siklus selama \pm 385 hari serta rentang perubahan $\pm 60 \mathrm{~cm}$. Berdasarkan hal tersebut maka hipotesis pada penelitian ini adalah bahwa MSL bulanan juga memiliki sifat cyclostationarity. Rumusan masalah dalam penelitian ini adalah: "Apakah fungsi gelombang dapat menjadi model yang mewakili terjadinya proses cyclostationarity perilaku MSL bulanan untuk dijadikan model koreksinya? Berapakah variasi MSL bulanan pada wilayah studi?". Penelitian ini bertujuan memodelkan terjadinya proses cyclostationarity untuk dijadikan sebagai model koreksi mean sea level bulanan dan untuk mengetahui variasi yang terjadi. Dengan mengetahui model koresi MSL bulanan maka hasil penelitian ini dapat dimanfaatkan untuk mengetahui prediksi perilaku dan memberikan koreksi MSL bulanan di luar data yang ada. Batasan-batasan yang diterapkan dalam penelitian ini di antaranya: panjang data pasut yang digunakan dalam penelitian selama \pm 8,2 tahun, penerapan metode analisis harmonik kuadrat terkecil untuk mendapatkan MSL bulanan, pemodelan fungsi gelombang menggunakan analisis harmonik kuadrat terkecil melalui fungsi deret Fourier, serta pengujian hubungan antara data dan model menggunakan analisis korelasi. 


\section{METODOLOGI}

Metodologi yang dilakukan untuk mengetahui model dan variasi MSL bulanan yang terjadi di Cilacap dan analisis penelitian ini adalah MSL bulanan pada data pasut sepanjang 8,2 tahun seperti yang dapat dilihat pada Gambar 1.

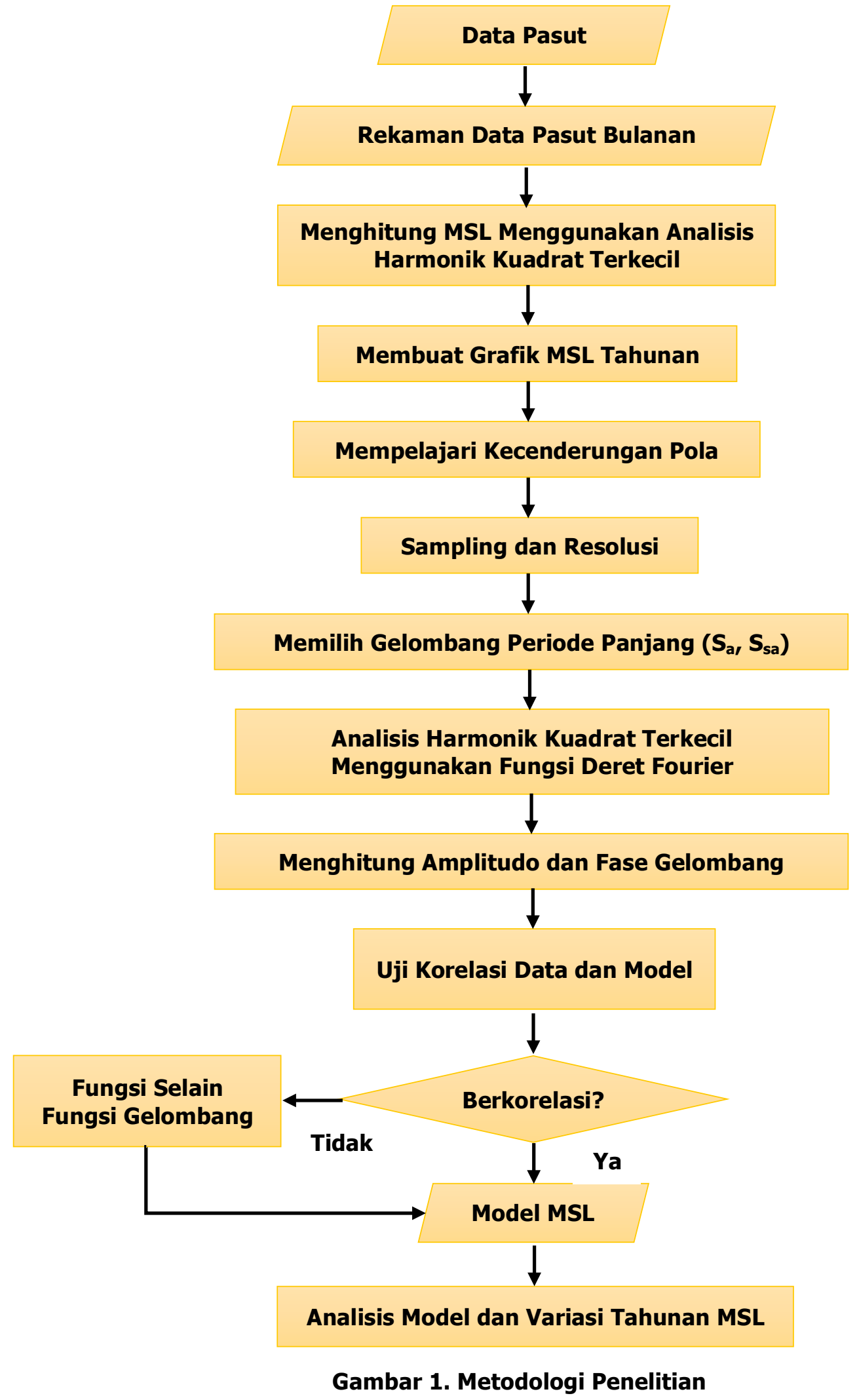

Reka Geomatika - 14 
Data pasut yang digunakan adalah data pengamatan tahun 2007 sampai dengan 2015 selama 3003 hari ( \pm 8,2 tahun) di Stasion Cilacap-B yang bersumber dari Sea Level Center, University of Hawaii. Pemilihan rentang waktu pengamatan yang panjang berdasarkan pertimbangan Perbani (2013) bahwa hasil penelitian proses cyclostationarity untuk pasang tinggi memerlukan data pasut lebih dari dua tahun. Ilustrasi data dapat dilihat seperti pada Gambar 2.

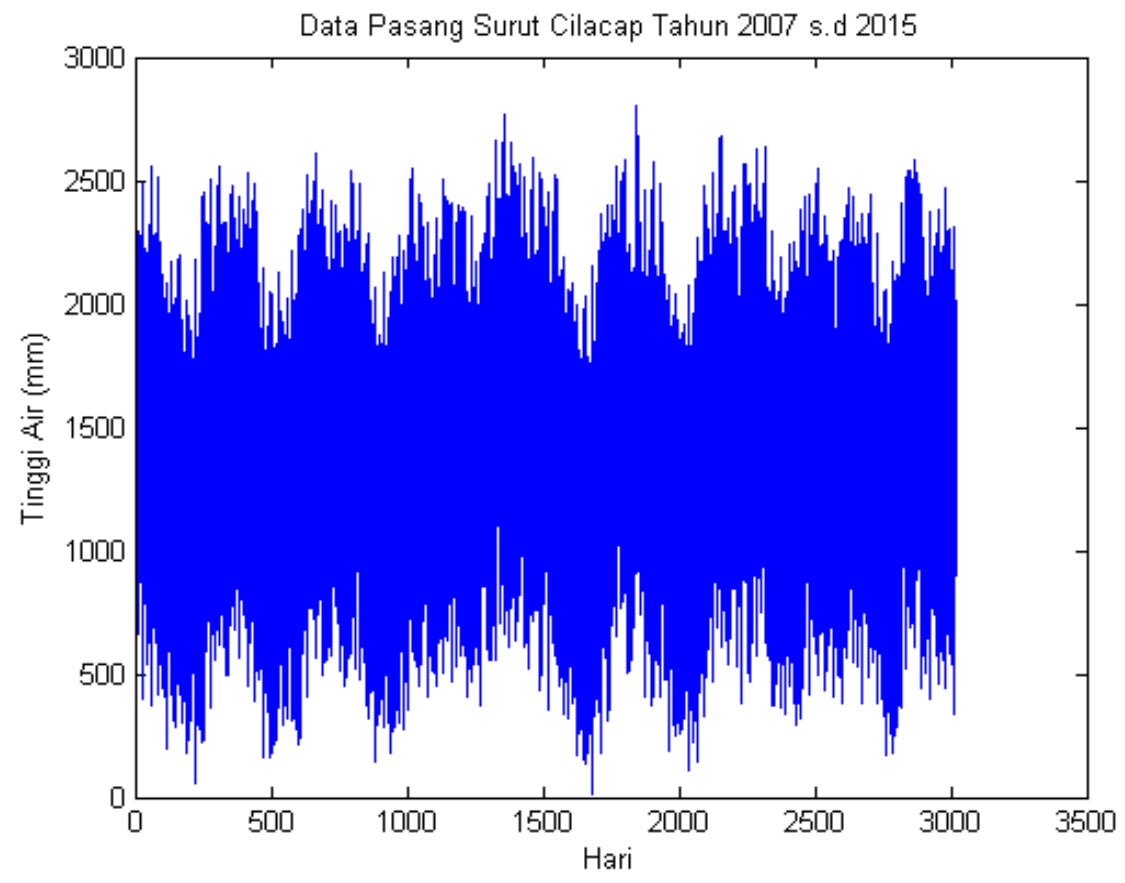

Gambar 2. Data Pasut Cilacap Tahun 2007-2015 (sumber data: Sea Level Center, University of Hawaii)

Dalam pemilihan konstanta pasut yang akan digunakan untuk menghitung MSL bulanan dan model proses cyclostationarity-nya harus memenuhi kriteria rentangan frekuensi gelombang serta bebas dari aliasing di mana frekuensi terendah dapat dihitung dengan $\varpi_{0}=\frac{2 \pi}{T}$ dan frekuensi terbesar $\varpi_{N}=\frac{\pi}{\Delta t}$. Resolusi $\Delta \varpi=\frac{2 \pi}{T}$ di mana $\mathrm{T}$ merupakan panjang data dan $\Delta t$ merupakan selang antar pengamatan. Koefisien korelasi antara data dan model dihitung menggunakan persamaan (Chapra, 1988):

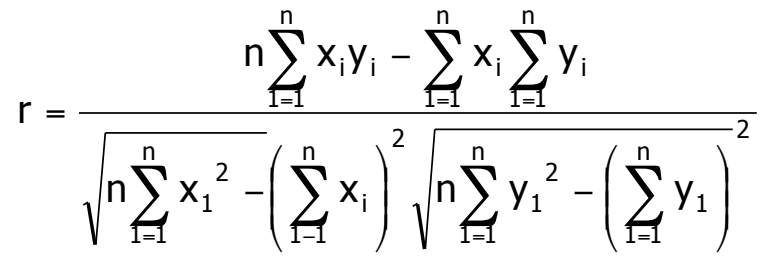

\section{HASIL DAN PEMBAHASAN}

\subsection{Pencuplikan Data Bulanan}

Penentuan pencuplikan data pasut menjadi data bulanan didukung oleh fakta bahwa pengamatan pasut yang selama ini dilakukan terutama untuk keperluan data teknis adalah 
selama 15 atau 29 hari. Data pengamatan periode pendek ini tidak dapat digunakan untuk menganalisis gelombang panjang. Penelitian ini dimaksudkan untuk mengeksplorasi permasalahan pada data periode pendek tersebut. Menurut Pugh (1996) dalam Perbani (2013), muka laut rata-rata periode panjang bukan merupakan fungsi dari waktu. Dari hasil hitungan MSL bulanan berdasarkan data pasut Stasion Cilacap-B yang telah melalui proses pencuplikan serta pengolahan analisis kuadrat terkecil dapat dilihat representasi trend MSL yang bervariasi terhadap waktu seperti pada Gambar 3. Hal ini membuktikan MSL dari data pengamatan satu bulan masih menunjukkan adanya variasi terhadap waktu karena pengaruh gelombang-gelombang yang tidak dapat tereksplorasi dari data bulanan tersebut. Variasi MSL bulanan dari Maret 2007 sampai dengan Mei 2015 di Stasion Cilacap-B dapat dilihat pada Tabel 1.

Tabel 1. Variasi MSL Bulanan

\begin{tabular}{lr}
\hline Maksimum $(\mathrm{mm})$ & 1681 \\
\hline Minimum $(\mathrm{mm})$ & 1031 \\
\hline Range $(\mathrm{mm})$ & 649 \\
\hline
\end{tabular}

Nilai maksimum MSL bulanan sebesar $1681 \mathrm{~mm}$ terjadi pada bulan November 2010, sedangkan nilai minimum sebesar $1031 \mathrm{~mm}$ terjadi pada bulan Agustus 2011. Range yang terjadi pada MSL bulanan di Stasion Cilacap-B tahun 2007 hingga 2015 mencapai sekitar 649 $\mathrm{mm}$.

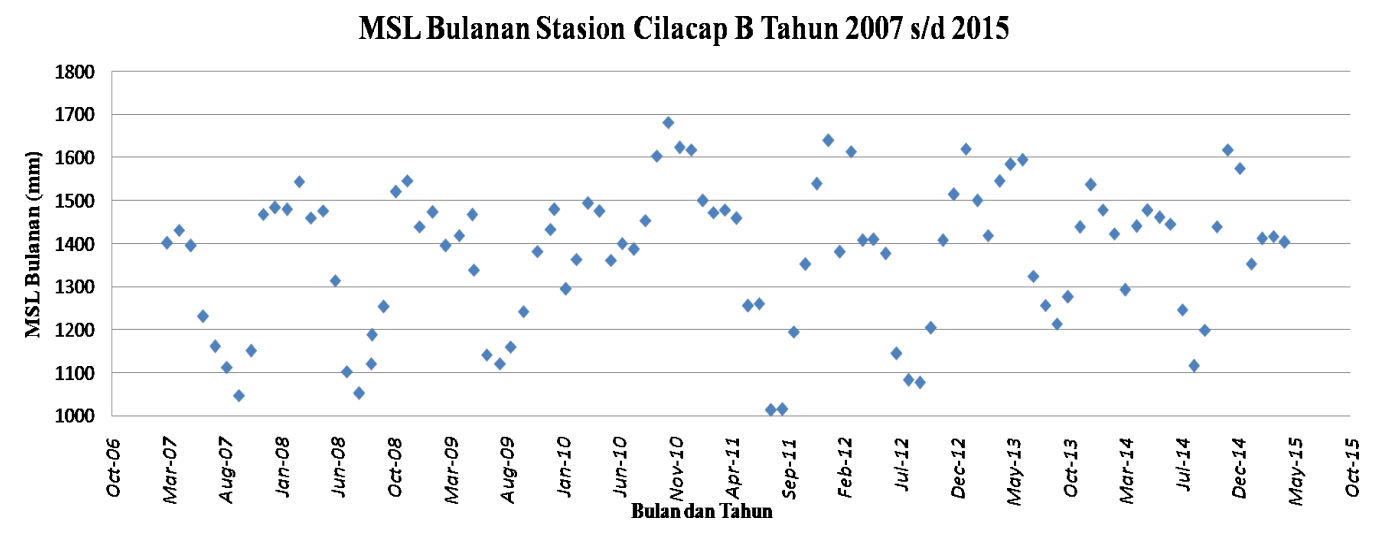

Gambar 3. Tren MSL Bulanan

\subsection{Sampling dan Resolusi}

Menurut Pugh (1996) dalam Perbani (2013), uji sampling ditujukan dalam memilih batasan frekuensi gelombang yang dapat dianalisis. Adapun uji resolusi ditujukan untuk menghindari aliasing di antara gelombang. Dalam pemilihan konstanta yang akan digunakan harus memenuhi kriteria rentangan frekuensi gelombang serta bebas dari aliasing. Data pasut bulanan di Stasion Cilacap-B yang dicuplik dari data tahunan memiliki data paling pendek 18,29 hari di bulan Februari 2009. Dalam perhitungan MSL bulanan dipertimbangkan menggunakan empat konstanta pasut utama yang dapat dilihat pada Tabel 2. Menurut Perbani (2013), resolusi untuk dapat memisahkan dengan baik keempat konstanta tersebut minimal 354,4 jam ( $\approx 15$ hari). Dengan demikian data di bulan Februari 2009 masih 
dinyatakan layak untuk digunakan dalam menentukan MSL bulanan. Berdasarkan perhitungan uji sampling dan resolusi pada MSL bulanan dengan selang data satu jam didapatkan hasil frekuensi terendah $\omega_{0}$ sebesar $0,008456508 \mathrm{rad} / \mathrm{jam}$ dan frekuensi tertinggi $\omega_{\mathrm{N}}$ sebesar 3,141592654 rad/jam Oleh karena itu keempat gelombang pasut pada Tabel 2 yang dipilih untuk digunakan dapat dikatakan layak dan memenuhi syarat.

Tabel 2. Konstanta Pasut untuk Menghitung MSL Bulanan

\begin{tabular}{crc}
\hline Komponen & Periode (Hari) & Frekuensi (rad/jam) \\
\hline $\mathrm{M}_{2}$ & 12,42060127 & 0,5058680 \\
\hline $\mathrm{S}_{2}$ & 11,99986267 & 0,5235988 \\
\hline $\mathrm{K}_{1}$ & 23,93453549 & 0,2625162 \\
\hline $\mathrm{O}_{1}$ & 25,81926525 & 0,2433519 \\
\hline
\end{tabular}

Pemilihan gelombang yang digunakan untuk menganalisis perilaku MSL bulanan juga menerapkan kriteria sampling dan resolusi. Dengan panjang data selama 72095 jam dan selang waktu data selama 743 jam maka didapatkan frekuensi terendah $\omega_{0}$ sebesar $0,00008715 \mathrm{rad} / \mathrm{jam}$ dan frekuensi tertinggi $\omega_{\mathrm{N}}$ sebesar $0,004228254 \mathrm{rad} / \mathrm{jam}$. Dari hasil sampling dan resolusi tersebut maka pada penelitian ini dipilih dua konstanta gelombang pasut yang memenuhi syarat bebas dari aliasing yaitu $S_{a}$ dan $S_{s a}$ dimana resolusi untuk dapat memisahkan kedua konstanta $\Delta \omega_{\text {Sa-Ssa }}=0,000716755 \mathrm{rad} / \mathrm{jam}$. Dengan frekuensi yang dapat dilihat pada Tabel 3, sedangkan gelombang-gelombang seperti $M_{m}, M_{s f}$ dan $M_{f}$ tidak dapat digunakan karena gelombang-gelombang tersebut tidak dapat dianalisis menggunakan data yang tersedia.

Tabel 3. Konstanta Pasut yang Dipertimbangkan untuk Analisis dan Perilaku MSL Bulanan

\begin{tabular}{crc}
\hline Komponen & Periode (Hari) & Frekuensi (rad/jam) \\
\hline $\mathrm{M}_{\mathrm{m}}$ & 27,55463190 & 0,009501103 \\
\hline $\mathrm{S}_{\mathrm{sa}}$ & 182,6281802 & 0,001433510 \\
\hline $\mathrm{S}_{\mathrm{a}}$ & 365,2563604 & 0,000716755 \\
\hline $\mathrm{M}_{\mathrm{sf}}$ & 14,76529444 & 0,017730726 \\
\hline $\mathrm{M}_{\mathrm{f}}$ & 13,66063078 & 0,019164236 \\
\hline
\end{tabular}

\subsection{Pemodelan Menggunakan Fungsi Gelombang}

Menurut Perbani (2013), seperti halnya pasang tinggi yang memiliki sifat cyclostationarity maka MSL bulanan pada penelitian ini diasumsikan memiliki sifat yang sama. Fungsi gelombang merupakan fungsi yang dapat mewakili fenomena-fenomena periodik, karenanya pada penelitian ini digunakan fungsi gelombang untuk memodelkan proses cyclostationarity MSL bulanan. Proses pemodelan menggunakan fungsi gelombang untuk mewakili proses cyclostationarity yang dihitung menggunakan metode analisis harmonik kuadrat terkecil melalui fungsi deret Fourier. Pertimbangan menggunakan deret Fourier terlebih dahulu karena dalam konsep hitung perataan kuadrat terkecil deret Fourier merupakan fungsi yang bersifat linear sehingga tidak diperlukan proses linearisasi dan penggunaan nilai pendekatan. 
Penggunaan deret Fourier sendiri didasari oleh sifatnya yang dapat mewakili suatu fenomena yang berulang terhadap waktu dan memiliki periodesitas, amplitudo, dan fase.

Dari hasil perhitungan analisis harmonik kuadrat terkecil untuk MSL bulanan didapatkan nilai dari amplitudo dan fase gelombang $S_{a}$ dan $S_{\text {sa }}$ yang dapat dilihat pada Tabel 4. Simpangan maksimum terhadap MSL bulanan rata-rata adalah $25 \mathrm{~cm}$. Sedangkan MSL bulanan rataratanya sebesar 1372 mm. Dengan demikian model perilaku MSL bulanan Stasion Cilacap-B dapat dinyatakan sebagai:

$$
\mathrm{MSL}(\mathrm{t})=\mathrm{MSL}_{\text {rata-rata }}+\mathrm{Amp}_{\mathrm{S}_{\mathrm{a}}} \cos \left(\omega_{\mathrm{S}_{\mathrm{a}}} \mathrm{t}-\phi_{\mathrm{S}_{\mathrm{a}}}\right)+\mathrm{Amp}_{\mathrm{sa}} \cos \left(\omega_{\mathrm{Ss}_{\mathrm{a}}} \mathrm{t}-\phi_{\mathrm{S}_{\mathrm{as}}}\right)
$$

sehingga:

$$
\begin{aligned}
\operatorname{MSL}(t) & =1372+160 \cos (0,000716755 t-1,702050446)+ \\
& +86 \cos (0,00143351 t-5,209512249)
\end{aligned}
$$

di mana MSL dalam mm, t (dinyatakan dalam jam) merupakan selang waktu dari waktu tengah pengamatan 1 April 2011 jam 00.00 WIB, dan sudut untuk menghitung cosinus

\begin{tabular}{|c|c|c|}
\hline Komponen & Amplitudo (mm) & Phase \\
\hline $\mathrm{S}_{\mathrm{a}}$ & 159,83580 & 1,702050446 \\
\hline $\mathrm{S}_{\mathrm{sa}}$ & 85,96695 & 5,209512249 \\
\hline$\sum A m p=$ & 245,80275 & \\
\hline
\end{tabular}
menggunakan satuan radian/jam.

Tabel 4. Amplitudo dan Phase $S_{a}$ dan $S_{s a}$

Data dan model MSL bulanan yang dihasilkan dapat dilihat pada Gambar 4.

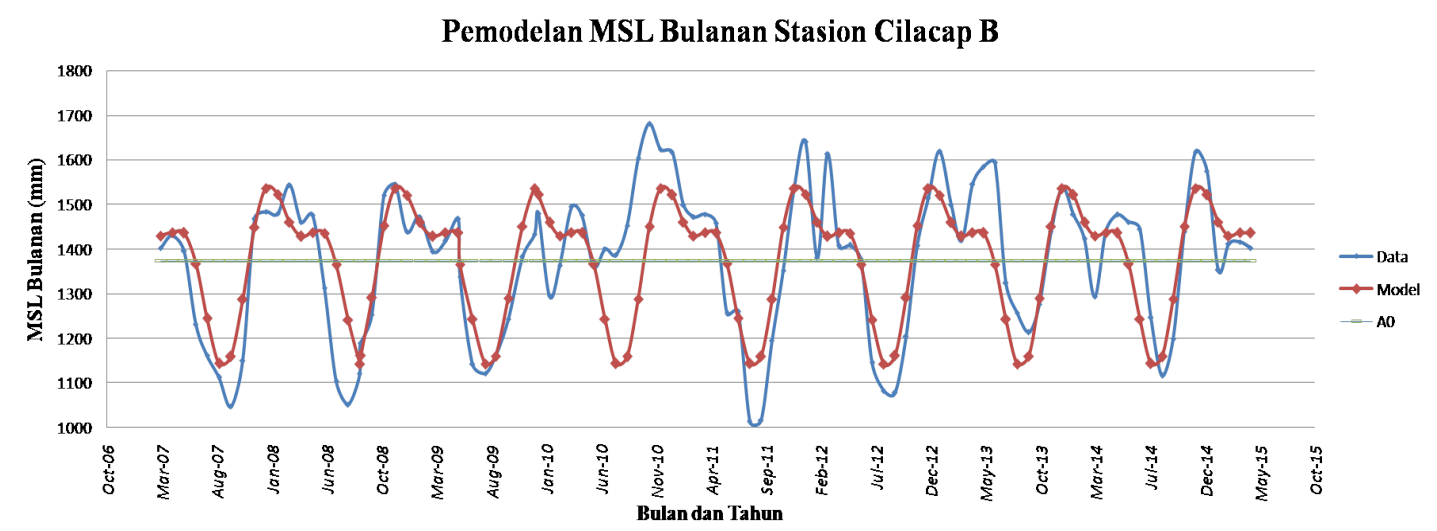

Gambar 4. Pemodelan MSL Bulanan

Pemodelan yang dilakukan menggunakan lebih dari satu gelombang. Adanya dua puncak di antara dua lembah gelombang seperti ditunjukkan pada Gambar 4 mengindikasi bahwa proses cyclostationarity dibangun oleh lebih dari satu gelombang. Hasil model sudah menunjukkan tren yang hampir mirip, hanya ada perbedaan yang cukup signifikan antara Juni hingga November 2010. Perbedaan ini masih terjadi karena pemodelan yang dilakukan 
pada penelitian belum memenuhi pemodelan MSL yang ideal di mana menurut Pugh (1996) dalam Perbani (2013), pemodelan MSL seharusnya juga mengakomodasi kecenderungan linear, pasut nodal periode 18,61 tahun, pengaruh meterologis, dan residu yang dinyatakan dalam Persamaan 4:

$$
\mathrm{Z}_{0}(\mathrm{t})=\overline{\mathrm{Z}_{0}}+\mathrm{at}+\mathrm{N}+\mathrm{S}_{\mathrm{a}}+\mathrm{S}_{\mathrm{sa}}+\mathrm{b}_{0} \mathrm{P}_{\mathrm{A}}+\mathrm{b} \frac{\partial \mathrm{P}_{\mathrm{A}}}{\partial \mathrm{x}}+\mathrm{b}_{2} \frac{\partial \mathrm{P}_{\mathrm{A}}}{\partial \mathrm{y}}+\mathrm{e}(\mathrm{t})
$$

di mana:

$$
\begin{aligned}
& \overline{\mathrm{Z}_{0}} \quad=\text { muka laut rata-rata periode panjang } \\
& \text { at } \quad=\text { kecenderungan linear } \\
& \mathrm{N} \quad=\text { pasut nodal periode 18,61 tahun } \\
& \mathrm{S}_{\mathrm{a}, \prime} \mathrm{S}_{\mathrm{sa}} \quad=\text { variasi tahunan dan suku harmonik pertama } \\
& \mathrm{P}_{\mathrm{A}}, \frac{\partial \mathrm{P}_{\mathrm{A}}}{\partial \mathrm{x}}, \frac{\partial \mathrm{P}_{\mathrm{A}}}{\partial \mathrm{y}}=\text { tekanan udara lokal } \\
& \mathrm{b}_{0}, \mathrm{~b}_{1}, \mathrm{~b}_{2}=\text { koefisien hubungan antara muka laut dan meterologi } \\
& \mathrm{e}(\mathrm{t})=\text { residu yang tidak termodelkan, } \\
& \text { termasuk juga kesalahan pengukuran }
\end{aligned}
$$

Penelitian ini baru memberikan kontribusi berupa dua faktor dari model pasut yang ideal dalam memberikan koreksi terhadap perhitungan MSL bulanan, yaitu variasi tahunan dan suku harmonik pertama (pengaruh gelombang tahunan $\mathrm{S}_{\mathrm{a}}$ dan setengah tahunan $\mathrm{S}_{\mathrm{sa}}$ ). Masih banyak faktor lain yang mempengaruhi MSL yang harus dikaji untuk menjadikan MSL menjadi bidang dengan kecenderungan linier atau dapat pula disebut bidang yang stasioner, di antaranya faktor meterologis dan kecenderungan selain fungsi gelombang.

Pada penelitian ini pemodelan proses cyclostationarity dilakukan dengan menggunakan fungsi gelombang yang bersuperposisi lebih dari satu gelombang, sehingga dalam penentuan periode konstanta pasut menggunakan dua konstanta pasut periode panjang yaitu $S_{a}$ dan $S_{s a}$. Dengan catatan, konstanta pasut yang dipilih haruslah memenuhi syarat dalam rentangan harga yang telah ditentukan pada sampling dan resolusi. $\omega_{0}$ sebesar $0,00008715147108 \mathrm{rad} / \mathrm{jam}, \omega_{\mathrm{N}}$ sebesar 0,004228254 rad/jam, $\Delta \omega$ sebesar 0,000716755 $\mathrm{rad} / \mathrm{jam}$.

\subsection{Uji Korelasi}

Hubungan antara data dan model untuk seluruh data MSL bulanan dari Maret 2007 sampai Mei 2015 di Stasion Cilacap-B dapat dilihat pada Gambar 5. Koefisien korelasi antara data dan model untuk seluruh data didapatkan sebesar 0,78 . Artinya metode yang dihasilkan $78 \%$ mewakili data. Perbedaaan yang cukup signifikan antara data dan model terjadi antara Juni sampai November 2010, sehingga dicoba untuk tidak mengikutkan hasil di antara periode tersebut di mana hasilnya dapat dilihat pada Gambar 6 sampai Gambar 9. 
Larasati S. Cendani, N.M.R.R. Cahya Perbani, Kania Sawitri

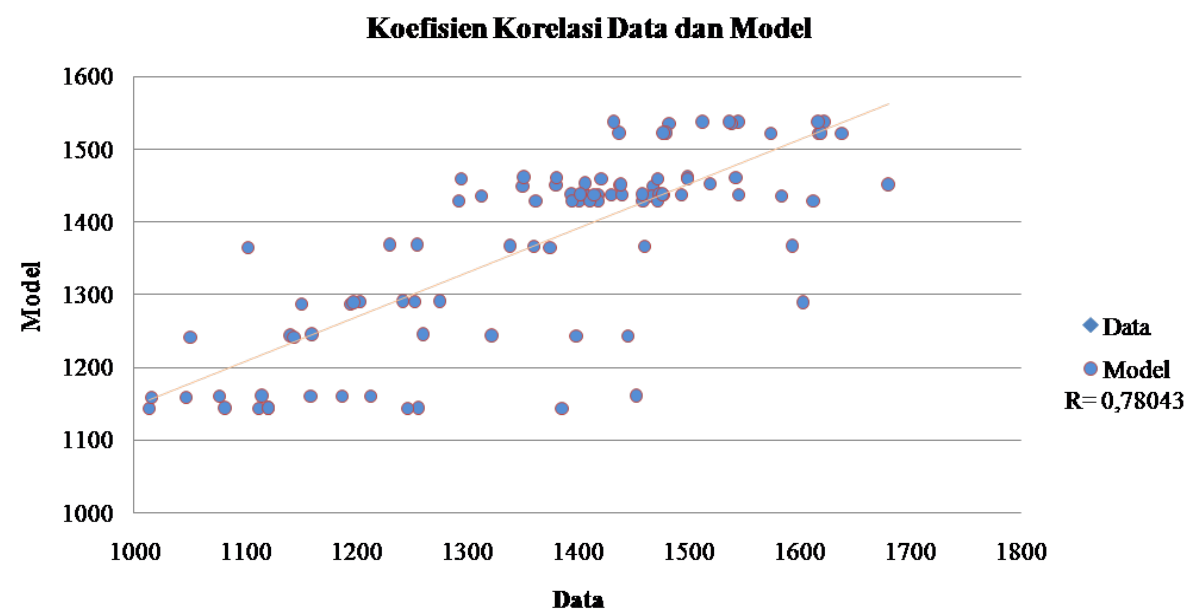

\section{Gambar 5. Hasil Uji Korelasi}

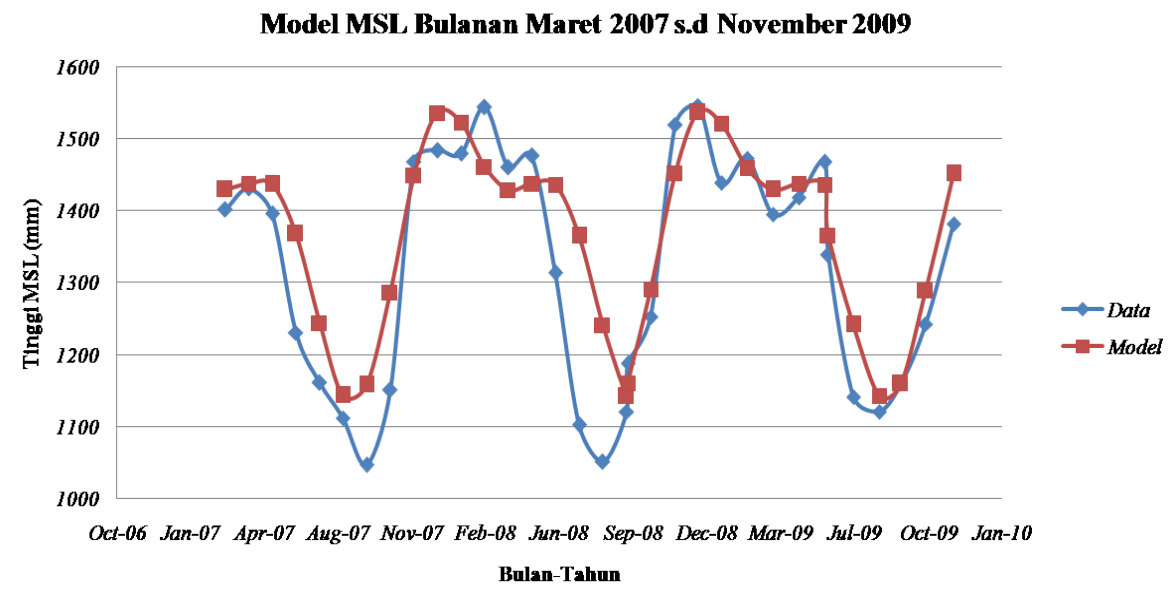

Gambar 6. Model MSL Bulanan

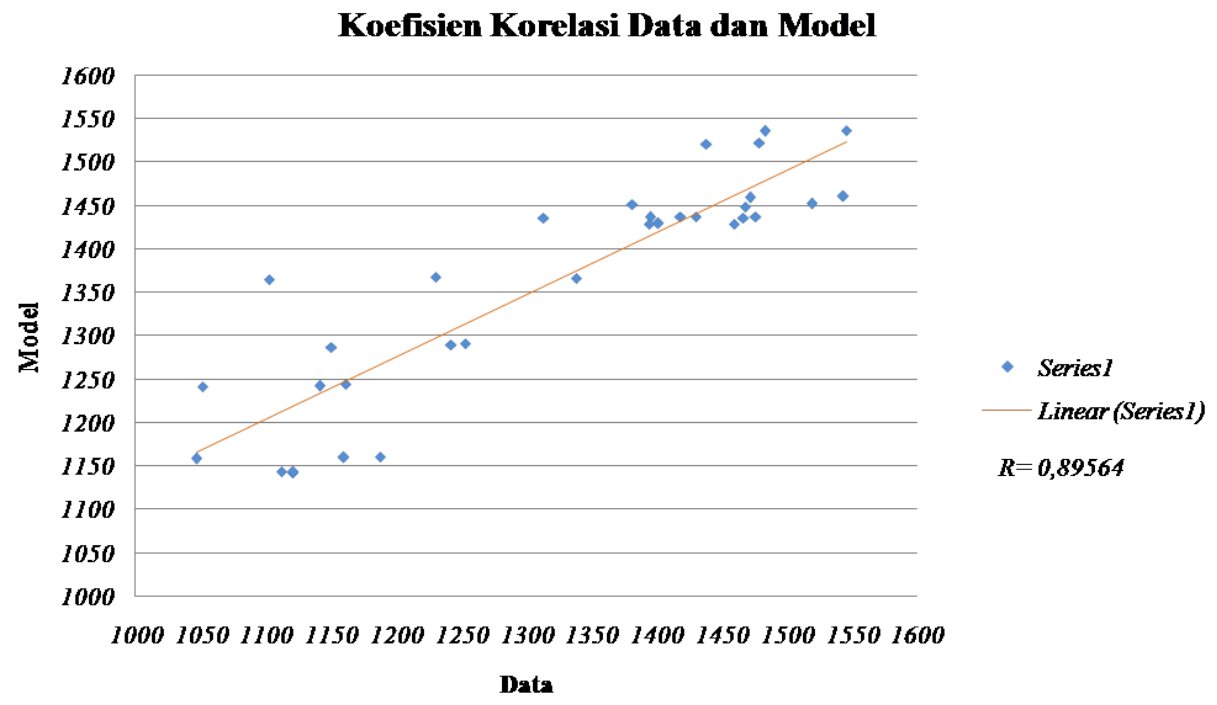

Gambar 7. Uji Korelasi

Reka Geomatika - 20 


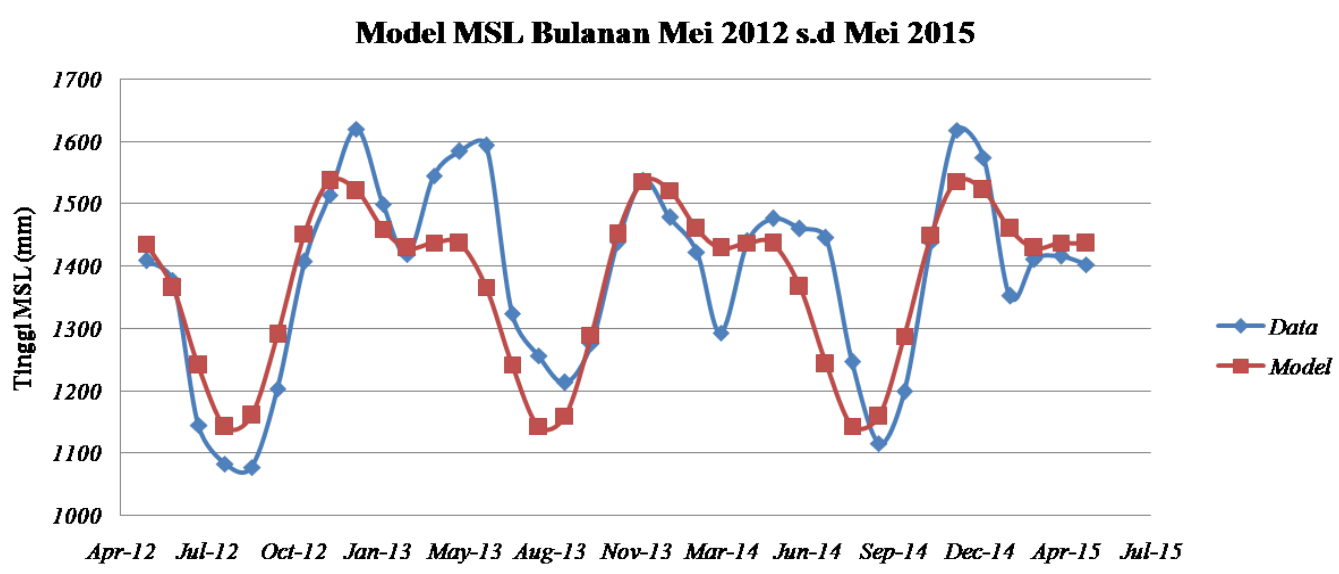

Bulan-Tahun

Gambar 8. Model MSL Bulanan

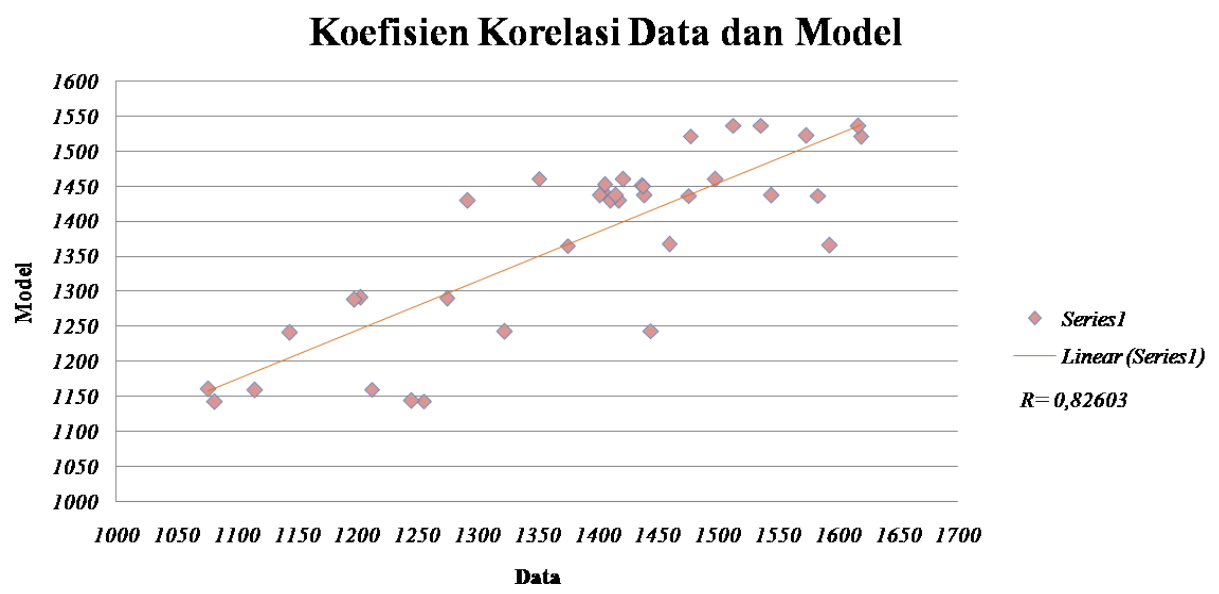

Gambar 9. Hasil Uji Korelasi

Koefisien korelasi antara data dan model MSL bulanan antara Maret 2007 sampai November 2009 sebesar 0,89. Adapun antara Mei 2012 sampai Mei 2015 sebesar 0,83. Hasil yang diperoleh ini mengindikasikan bahwa model MSL bulanan yang dihasilkan pada penelitian ini sudah lebih dari $80 \%$ mewakili data dan sudah cukup signifikan dalam memberikan kontribusi untuk memberikan koreksi terhadap hasil MSL dari data pasut bulanan di Stasion Cilacap-B.

\section{KESIMPULAN}

Pada penelitian yang telah dilakukan dalam memodelkan terjadinya proses cyclostationarity MSL bulanan pada data pasut Stasion Cilacap-B selama $\pm 8,2$ tahun maka dapat ditarik kesimpulan sebagai berikut: (1) model yang dihasilkan dengan fungsi gelombang menggunakan dua konstanta pasut periode panjang $S_{a}$ dan $S_{\text {sa }}$ sudah mewakili sekitar $80 \%$ perilaku MSL bulanan; (2) model MSL (t) dalam $\mathrm{mm}=1372+160 \cos (0,000716755 \mathrm{t}-$ $1,702050446)+86 \cos (0,00143351 \mathrm{t}-5,209512249)$ dapat digunakan untuk memberikan koreksi di luar data dengan t (dalam jam) merupakan selang waktu dari waktu tengah pengamatan 1 April 2011 jam 00.00 WIB, dan sudut untuk menghitung cosinus 
menggunakan satuan radian/jam; (3) nilai maksimum MSL bulanan sebesar $1681 \mathrm{~mm}$ terjadi pada bulan November 2010, sedangkan nilai minimum sebesar $1032 \mathrm{~mm}$ terjadi pada bulan Agustus 2011. Range yang terjadi pada MSL bulanan di Stasion Cilacap-B tahun 2007 sampai dengan 2015 mencapai sekitar $65 \mathrm{~cm}$; (4) simpangan maksimum terhadap MSL bulanan rata-rata adalah $25 \mathrm{~cm}$.

\section{DAFTAR PUSTAKA}

Chapra, S. C. dan Canale, R. P. (1988). Numerical Methods for Engineers. New York McGraw-Hill Book Company,

Huang, Z., Chen, Z., Si, C., dan Ye, L. (1997). Analysis of 19-Year Tidal Data. Science in China Series D: Earth Sciences, 40 (4), 352-360.

Mochamad, F. (2008). Pemanfaatan Data GPS Kontinu Menuju Survei Batimetrik Real Time. Skripsi Institut Teknologi Bandung, Bandung.

Perbani, N. M .R. R. C. (2010). Studi Proses Cyclostationarity untuk Prediksi Tinggi Pasut. Jurnal Rekayasa Itenas, 14 (3).

Perbani, N. M .R. R. C. (2013). Investigasi Variasi Tahunan terhadap Mean Sea Level di Benoa, Bali. Jurnal Rekayasa Itenas, 17 (1). 